\title{
ЗМІСТ ЕКОЛОГІЧНОЇ ОСВІТИ В ПРЕДМЕТАХ ІНТЕГРОВАНИХ КУРСІВ В СЕРЕДНІЙ ШКОЛ СЛОВАЧЧИНИ
}

8. Tovkanets, H. V. \& Horvat, S.V. (2017). Telekomunikatsiinyi proekt yak osvitnia tekhnolohiia [Telecommunication project as educational technology]. Education and formation of competitiveness of specialists in the conditions of European integration: collection of abstracts of the International scientific-practical conference (October 26-27, 2017, Mukachevo). Mukachevo, pp. $95-96$ [in Ukrainian].

9. Fedorchuk, V. (2012). Elektronnyi pidruchnyk yak zasib informatyzatsii suchasnoi osvity [Electronic textbook as a means of informatization of modern education]. Pedagogical education: theory and practice. Vol. 12.pp. 153-158. Available at: http://nbuv.gov.ua/UJRN/znppo_2012_12_29. [in Ukrainian].

10. Fihol, N. (2014). Struktura elektronnoho navchalnoho vydannia [The structure of the electronic educational publication]. Bulletin of the Book Chamber. No. 7.pp. 29-31. [in Ukrainian].

11. Shevchenko, V. L. (2008). Osnovy dydaktychnoho proektuvannia kompiuterno oriientovanykh navchalnykh kompleksiv dlia dystantsiinoi osvity: navchalnometodychnyi posibnyk [Fundamentals of didactic design of computer-oriented educational complexes for distance education: a textbook]. Kyiv, 152 p. [in Ukrainian].

Стаття надійшла до редакції 10.11.2020

УДК 373:364

DOI:

Оксана Турок, вчитель біологї Рахівського закладу загальної середньої освіти I-III ступенів № 1, здобувач ступеня доктора філософії

\section{ЗМІСТ ЕКОЛОГІЧНОЇ ОСВІТИ В ПРЕДМЕТАХ ІНТЕГРОВАНИХ КУРСІВ В СЕРЕДНІЙ ШКОЛІ СЛОВАЧЧИНИ}

У статті розглянуто основні способи впровадження екологічної освіти як наскрізної теми в освітній процес середньої школи Словаччини. Визначено основні способи формування екологічної компетенції учня та виокремлено теми у змісті інтегрованих курсів, в яких екологічна освіта є наскрізною темою. Акцентовано увагу на злагодженій роботі формальної і неформальної екологічної освіти в середній школі Словацькоі Республіки. Доведено, що модулі навчальних курсів “Феномени світу” та інтегроване етичне виховання сприяють розвитку екологічної компетенції учня.

Ключові слова: екологічна освіта; наскрізна екологічна освіта; середня школа; освіта Словаччини; формування екологічної компетенції.

Лim. 8.

Oksana Turok, Teacher of Biology, Rakhiv Establishment of General Secondary Education of I-III degrees № 1, Applicant of the degree of Doctor of Philosophy

\section{THE SUBJECTS OF INTEGRATED COURSES IN SECONDARY SCHOOLS OF SLOVAKIA}

The article considers the main ways of introducing the cross-cutting theme of environmental education into the educational process of high school students in Slovakia. An environmental education of the younger generation is becoming increasingly important in the context of the intensifying environmental crisis and its consequences for the wellfare and well-being of everyone. The ways of the formation of the student's ecological competence during studying of various subjects have been defined. It has been emphasized that there is the need to include environmental topics in the study of subjects not only in the natural cycle such as Physics, Chemistry, and Biology. An accent has been placed on the positive experience of using the subjects of integrated courses in the educational process of secondary school in the Slovak Republic. The importance of coordinated work of formal and non-formal education has been shown. The documents influencing the formation of the educational process of the Slovak secondary school have been analyzed.

The expediency of introduction of new educational standards has been substantiated, which gives the chance to form ecological competence of the graduate of the second degree of high school of Slovakia (the 9th grade) through mastering of themes of integrated courses and subjects of the basic cycle. It has been established that integrated courses have been introduced into the educational process of secondary school in accordance with the updated educational programmes of the Slovak secondary school and world trends in the reform of the secondary education system. The general tendencies of the formation of ecological education of high school students have been singled out. It has been proved that the modules of the training courses "Phenomena of the World" and integrated aesthetic education contribute to the development of ecological competence of the student. The content of the integrated courses "Phenomena of the World" and integrated aesthetic education have been analyzed and revealed and it has been indicated in which specific topics the student's ecological competence has been formed. It has been 


\section{ЗМІСТ ЕКОЛОГІЧНОЇ ОСВІТИ В ПРЕДМЕТАХ ІНТЕГРОВАНИХ КУРСІВ В СЕРЕДНІЙ ШКОЛІ СЛОВАЧЧИНИ}

concluded that the school's use of the possibility of introducing integrated courses into the educational process contributes to the development of environmental competence of a students of the school that does not have an environmental specialization.

Keywords: an ecological education; crosscutting ecological education; secondary school; an education in Slovakia; formation of ecological competence.

П остановка проблеми. Критична ситуація, в якій сьогодні опинилося людство, пов'язанез антропоцентричним ставленням кількох поколінь до природних ресурсів. Забруднення вод Світового океану, грунтів та повітря досягло таких масштабів, що майже вся їа, яку споживає людина, насичена мікропластиком та іншими речовинами, що спричиняють шкоду здоров'ю. Така глобальна екологічна проблема, як зміни клімату та, як наслідок, пов'язані з нею зниження урожайності рослин, інвазія нових видів, повені, зсуви, штормові вітри, та, пересихання водотоків на тривалий час, зараз торкаються благополуччя кожної людини. Екологічна освіта сприяє розвитку визначальних компетенцій випускника середньої школи таких, як критичне мислення, медіаграмотність, вміння приймати зважені рішення, передбачати наслідки власних дій, аргументовано доводити власну думку, працювати в команді тощо. Наразі екологічна освіта $\epsilon$ вектором розвитку особистості та безперервної освіти протягом життя.

Метою статті $\epsilon$ дослідження екологічної складової у змісті інтегрованих предметів для формування екологічної компетенції учнів словацької середньої школи.

Аналіз основних досліджень та публікацій. Проблеми становлення екологічної освіти в середній школі висвітлено в працях словацьких вчених: П. Адамішина, Е. Гутманової, Й. Турека. С. Вінцікової, Р. Медала та багатьох інших. Зокрема, словацька науковиця Р. Бернатова зазначає, що “базова школа відіграє значну роль у впровадження екологічної освіти учнів" та “має значну частку в придбанні екологічні знання та формування екологічних установок і поведінки учнів молодшого і старшого шкільного віку" [5, 23]. Вітчизняна дослідниця Г. Білавич засвідчує, що “енвайронментальна освіта сьогодні розвивається не лише як теорія, а радше як певна практика, спрямована на формування екологічно орієнтованої т. зв. життєвої політики суспільства" $[1,33]$.

Виклад основного матеріалу. Екологічна освіта в Словаччині регламентується документами міжнародного та національного рівнів (Законом про освіту, Законом про охорону навколишнього середовища, Цілями Тисячоліття тощо) та здійснюється як у формальній сфері, так і в неформальній. Неформальна освіта здійснюється
Міністерством охорони навколишнього середовища та неурядовими організаціями [2; 3]. Формування екологічної компетенції відбувається не за рахунок впровадження в освітній процес окремого предмету, а через наскрізну тему "Екологічна освіта" [8]. Наразі оновлений стандарт освіти (2015) визначає сім наскрізних тем: особистий і соціальний розвиток, екологічна освіта, медіальна освіта, мультикультурна освіта, навчання дорожнього руху, навчання безпеки на дорозі, захист життя та здоров'я, створення проекту та презентаційні навички. Варто зазначити, що в середній школі Словацької Республіки екологічна освіта в початковій школі представлена досить змістовно та розкрита в різних формах $[5,23]$. Державна освітня програма для II ступеня словацької школи (5-9-й класи) ISCED 2 вказує, що школа може створити новий предмет на основі примітки 6 "Школа використовуватиме факультативні (доступні) уроки для заповнення шкільної програми. Необов'язкові (доступні) уроки можуть бути використані для предметів, які школа вибирає та готує власний зміст, включаючи предмети, що створюють шкільний профіль, та експериментально підтверджених інноваційних програм, що впроваджуються у практику викладання" $[8,4]$.

Нами досліджено впровадження екологічної освіти в середній школі Словацької Республіки на прикладі школи I та II ступеня в Горках (Жилін), яка не має спеціального профілю. Спостерігаємо в шкільній навчальній програмі серед цілей таку: "побудова системи цінностей особистості шляхом екологічного виховання, естетичного виховання, здорового способу життя - фізичного та психічного, здорового харчування" $[6,8]$, а серед вимог до випускника II ступеня (9-й клас) “вміти сприймати природу в цілому, поважати всі форми та типи життя" $[6,11]$. Реалізація екологічної освіти здійснюється у змісті предметів “Феномени світу", біологія, фізика, математика, географія, художня освіта, інтегроване етичне виховання, технології [7, 3-6]. Метою наскрізної екологічної освіти в темах названих предметів є: дотримуватися основних правил поведінки в природі щодо організмів та їх середовища; визначати та оцінювати зміни в природі та в іiі оточенні; знати можливості, що ведуть до охорони та поліпшення довкілля, брати участь у заходах, спрямованих на охорону та поліпшення більш 


\section{ЗМІСТ ЕКОЛОГІЧНОЇ ОСВІТИ В ПРЕДМЕТАХ ІНТЕГРОВАНИХ КУРСІВ В СЕРЕДНІЙ ШКОЛІ СЛОВАЧЧИНИ}

широкого навколишнього середовища (школи, муніципалітету); отримувати інформацію про втручання людей у навколишнє середовище та оцінювати наслідки на місцевому і у глобальному рівнях; розрізняти екологічно чисті технології та продукцію; економно ставитися до природних ресурсів; брати активну участь у ліквідації забруднення навколишнього середовища $[6,16]$.

Екологічна освіта та виховання учнів здійснюється також згідно $з$ річним планом в області екологічного виховання, що вибудуваний на співпраці вчителів різних предметів і різних класів та координується екологічним координатором [4]. Його основна мета “підвищити екологічну обізнаність учнів, навчати та виховувати учнів, чутливих та уважних до екологічних проблем, створювати та розвивати практичні навички учнів щодо захисту та покращення навколишнього середовища" [7,2].

Серед основних завдань шкільного плану екологічного виховання $€$ такі: підтримка та мотивація учнів до участі в екологічних конкурсах та проєктах, у мистецьких конкурсах 3 екологічних питань; спонукати учнів економити електроенергію та тепло, усвідомити необхідність зменшення споживання води, навчити їх дбайливо ставитися до шкільного приладдя та шкільного майна; висвітлювати екологічні теми на дошках оголошень; продовжувати організацію заходів у природі, поїздок та екскурсій з огляду на екологічні аспекти свого району; звернути увагу учнів на деякі важливі дати з екологічного календаря в аудиторіях та на уроках біології, хімії, географії, обговорити їх важливість, потребу та значення з точки зору суспільства (22 березня - Всесвітній день води, 1 квітня - Всесвітній День птахів, 7 квітня - Всесвітній день здоров'я, 22 квітня - день Землі, 5 червня - Всесвітній день довкілля, 3 жовтня - Всесвітній день навколишнього середовища, день тварин, 16 жовтня - День здорового харчування); навчити учнів захищати навколишнє середовище шляхом сортування вторинних відходів: збір паперу, збір використаних батарейок [7, 3-4]. На реалізацію цих завдань спрямовані теми предметів “Феномени світу” та інтегрованого етичного виховання.

Програма курсу “Феномени світу” (“Fenomйny sveta”) призначена для учнів II рівня початкової школи (5-9-й класи) та нижчих класів гімназій 3 восьмирічною освітньою програмою і орієнтована на пізнання явищ та процесів, пов'язаних з водою і повітрям. Феномен можна визначити як природне явище, реальність чи особистість, яка $є$ винятковою та унікальною. Світ навколо нас складний і пропонує кілька таких явищ. Вода, сонце, повітря, спілкування та культура - це унікальні явища у світі, які потребують міждисциплінарного підходу та всебічного розуміння контексту. Акцент на міждисциплінарності міститься у Державній освітній програмі, а також у Національній програмі розвитку освіти (20182027). У предметі “Феномени світу” міждисциплінарний підхід розуміється як “співпраця в рамках окремих предметів у даній освітній галузі, а також між різними сферами" [6, 2] та задуманий, що створює простір для міждисциплінарних відносин в межах індивідуальних знань, розуміння контексту та практичного впливу цього явища, а також для розвитку компетенцій. Для факультативного предмету “Феномени світу” школа виділяє загалом 33 навчальних години на рік: у п’ятому класі “Феномени світу - Вода”, у шостому класі “Феномени світу - Повітря”. За тематичним планом можна викладати 1 годину на тиждень або 2 години через тиждень. Засвоєння курсу сприяє формуванню таких компетентностей учня: критичне мислення, навички спілкування та презентаційні навички, творчість, відповідальність, вміння працювати в команді, розуміння читання та слухання. Навчальні моделі складаються 3 видів діяльності, в яких застосовуються різні методи навчання. Для потреб створення освітніх моделей були відібрані методи навчання, які використовуються в різних видах діяльності: керовані методи навчання, кінестетичні методи навчання, зворотне навчання, методи диференційованого навчання, методи дослідження, проєктні методи навчання, дидактичні ігри, гейміфікація, метод CLIL $[6,44]$.

Зміст курсу "Феномени світу - Вода" характеризується такими трьома основними ознаками: міждисциплінарність, орієнтація на компетенції, підтримка використання IКТ. Міждисциплінарний підхід приводить учнів до розуміння контексту та розвиває екологічне мислення [6, 42]. Тема води є змістовою частиною навчальної програми 3 різних загальноосвітніх предметів, наприклад, у фізиці, де учні мають справу з її станами, в хімії, де вони починають сприймати воду як хімічну речовину, в біології, де вода характеризується як умова життя, або в географії, де розуміється як геоморфологічний фактор. Таким чином, ми могли б перейти до історії, де вода стала способом відкриття нових світів, або до галузі літератури та мистецтва, де вона стала натхненням для творчості. Учні повинні зрозуміти практичний вплив фізичних явищ, пов’язаних 3 поведінкою тіл у воді, оцінити, як вода впливає на 


\section{ЗМІСТ ЕКОЛОГІЧНОЇ ОСВІТИ В ПРЕДМЕТАХ ІНТЕГРОВАНИХ КУРСІВ В СЕРЕДНІЙ ШКОЛІ СЛОВАЧЧИНИ}

ландшафт, розуміти їі важливість у природі та для людини, продумати способи охорони води, визначити основні екологічні проблеми, пов'язані 3 водою, планувати, проводити та оцінювати експерименти, аналізувати й критично оцінювати інформацію 3 різних джерел, оцінити та сформулювати основні умови життя, обговорювати, аргументувати та представляти результати командної роботи.

Основною концептуальною ідеєю предмета є екскурсія, в якій студенти шляхом власних активних досліджень та викладання на практиці поступово відкривають явище води з різних сторін. У першому розділі (перспектива “Як це працює”) основна увага надається фізикохімічним властивостям води, а також ії рухам у ландшафті. Вона націлена на практичне пояснення природних законів людського життя та природи. У розділі 2 (перспектива “Як це впливає на нас") основна увага зосереджується на з'ясуванні значення води в природі, а також іiі впливу на людство та суспільство. Розділ 3 (перспектива “Яка їі історія”) досліджує, як і коли вода вплинула на історію людства. Розділ 4 (перспектива: “Що робить їі унікальною”) досліджує, що робить феномен води винятковим 3 точки зору ширшого контексту досліджуваної теми. Отже, зміст предмету “Феномени світу Вода" поділено на чотири перспективи та 12 освітніх моделей (кожна перспектива містить три освітні моделі). Освітня модель - це всебічна тема, яка розвиває задану перспективу. Вона складається 3 3-5 навчальних заходів, що пов'язані зі змістом навчальних відео ВВС. Освітні моделі зосереджені на таких темах:

1. “Як це працює?” (Невелика молекула величезного значення, Слідами води в країні. Вода в русі).

2. Як це впливає на нас? (Без води не можна. Вода - рідкісна сировина. Вода призначена не тільки для пиття).

3. Яка іiі історія? (Вік пари. Вода як кордон i дорога. Цивілізації великих річок)

4. Що робить іiі унікальним? (Стихійні лиха. Життя на Марсі. У країні крижаного королівства).

Згідно з освітнім стандартом предмету “Феномени світу - Вода" наскрізну екологічну тему відслідковуємо у змісті навчання тематичних блоків "Яка її історія?”: “Вік пари”, “Вода як кордон і дорога”, “Цивілізація великих річок” (7 годин) та “В чомуії особливість”: “Стихійні лиха”, “Життя на Марсі”, “У країні крижаного королівства" (9 годин) [6, 49].

У темах модулів освітнього стандарту “Як вода впливає на нас” i “Без води не можна” учень повинен вміти/знати: спостерігати за спільними та різними ознаками груп організмів; пояснювати пристосованість організмів до певного середовища; обробляти інформацію про окремі громади, отриману з різних джерел; проводити простий експеримент або спостереження для вивчення процесів життєдіяльності організмів; обгрунтовувати пристосування структури тіла рослини до навколишнього середовища у формі експерименту для розуміння руху води в тілі рослини; навести і сформулювати основні умови життя.

У модулі "Вода - рідкісна сировина" учень знає / вміє: оцінювати значення води для життя 3 точки зору причин та наслідків їі забруднення; наслідки забруднення повітря, води та грунтів на життя; аргументувати позитивні та негативні сторони промисловості, транспорту, енергетики, сільського господарства, гірничої справи; проводити процедури розділення компонентів сумішей відповідно до інструкцій; досліджувати важливість збереження унікальних екосистем; моделювати процедури очищення води за допомогою простих експериментів; займати активну позицією щодо екологічних проблем $[6,46]$.

Значне екологічне наповнення простежуємо в освітньому модулі “Вода призначена не тільки для пиття”, наприклад, учень характеризує значення гідроелектростанцій як відновлюваного джерела енергії, пояснює на простих прикладах перетворення форм енергії, на прикладах аргументує позитивні та негативні риси відновлюваних та невідновлюваних джерел енергії. Також у модулі "Природні катастрофи" учні навчаються оцінювати вплив глобальних кліматичних змін на життя населення та "У країні Крижаного Королівства”, пояснюючи значення льодовиків для людини та глобального клімату, обгрунтунтовує екологічні ризики економічного використання полярних областей [6, 48-49].

Прикладом впровадження екологічної освіти як наскрізної теми може слугувати також інтегрований курс естетичного виховання (“Integrovaná estetická výchova”) у п’ятому, шостому та дев'ятому класах (1 година на тиждень) метою якого “є глобальний розвиток особистості 3 акцентом на ставлення до навколишнього середовища, його створення, захист та розвиток на місцевому, регіональному та міжнародному рівнях" [6, 134]. Ця тема реалізується на таких уроках в п’ятому класі: “Чи подобається природа людям”, “Яблуко”, “Чотири пори року”, “Доісторія” [6, 135], та в шостому класі: “Дерево”, “Місце, де я живу”, "Імпресіонізм”, “Людина - творець краси”, 


\section{ЗМІСТ ЕКОЛОГІЧНОӦ ОСВІТИ В ПРЕДМЕТАХ ІНТЕГРОВАНИХ КУРСІВ В СЕРЕДНІЙ ШКОЛІ СЛОВАЧЧИНИ}

“Скульптор”, “Враження”, “Тиша”, “Еколог”. До прикладу, в темі "Еколог" школярі активно створюють власну скульптуру з відходів та розуміють необхідність екологічних знань і природоохоронної діяльності для збереження краси $[6,138]$.

Метою предмету інтегроване етичне виховання у 9-му класі $\epsilon$ "глобальний розвиток особистості $з$ акцентом на ставлення до навколишнього середовища, його створення, захист та розвиток на місцевому, регіональному і міжнародному рівнях" [6, 142]. До прикладу, в темі “Дерева" учень навчається спостерігати за змінами в природі і висловлює їх художньо, естетично сприймати та художньо фіксувати цікаві природні факти $[6,140]$.

Аналіз освітніх програм курсів “Феномени світу" та інтегрованого етичного виховання доводить, що екологічна складова представлена досить глибоко в молодших класах середньої школи Словаччини та значно менше в дев'ятому класі.

Висновки та перспективи подальших досліджень. Реалізація екологічної освіти як наскрізної теми в середній школі здійснюється у змісті інтегрованих курсів "Феномени світу" ("Fenomény sveta") в 5 і 6 класах та інтегроване етичне виховання "Integrovaná estetická výchova" в 5, 6 і 9 класах, а також, згідно $з$ планом екологічного виховання школи, що координується роботою шкільного екологічного координатора. Ми вважаємо, що екологічне виховання учнів 5-9 класів середньої школи є достатнім та різностороннім, відповідає віковим нормам, інтересам учнів та вимогам суспільства. Включає в себе роботу на уроках під час вивчення різних тем предметів природничого та суспільного циклів і в позаурочний час: заходи, проєктна діяльність, участь у тематичних днях, школах в природі тощо. Перспективи подальших досліджень вбачаємо в дослідженні підготовки вчителів до викладання екологічної освіти як наскрізної теми в словацькій середній школі та шляхів реалізації екологічної освіти як наскрізної теми в українській середній школі.

\section{ЛITEРАТУРA}

1. Білавич Г. Енвайронментальна освіта для сталого розвитку у вимірі ЮНЕСКО крізь призму підручникотворення. Молодь і ринок. Дрогобич, 2020. № 3-4 (182-183). С. 30-34.

2. Товканець Г.В., Турок О.С. Зміст освіти і виховання учнів середньої школи в діяльності словацьких екологічних організацій. Актуальні питання гуманітарних наук: міжвузівський збірник наукових праџь молодих вчених. Дрогобич, 2020. № 4 (30). С. 220-222.
3. Турок О.С. Екологічне просвітництво в умовах неформальної освіти у Словацькій республіці. Науковий вісник Мукачівського державного університету. Серія: Педагогіка та психологія. Мукачево, 2019, № 2 (10)' частина 2. С.93-96.

4. Турок О.С. Роль екологічного координатора в школах Словаччини. Scientific Collection "Inter.Conf", (31): with the Proceedings of the 7th International Scientific and Practical Conference Science and Practice: Implementation to Modern Society. Manchester, Great Britain (October 6-8, 2020). C.69-71.

5. Bernátová R. Environmentálna výchova - prierezová téma $\mathrm{v}$ základnej škole. Aktuálne otázky prírodovednotechnických predmetov a prierezových tém v primárnej edukácii Online konferencia 23-25.10.2013

6. Inovovaný školský vzdelávací program pre 1.a 2. Stupeň základnej školy s materskou školou Hôrky URL: https://zshorky.sk/wp-content/uploads/2019/10/ Inovovan \%C3\%BD-\%C $\%$ A 1 kolsk\%C3\%BDvzdel $\% \mathrm{C} 3 \% \mathrm{~A} 1$ vac\%C3\%AD-program-2020.pdf

7. Plán práce školy v oblasti: environmentálna výchova. Šk. rok: 2020 /2021 URL: https://zshorky.sk/wp-content/ uploads $/ 2020 / 10 /$ Koordin $\% \mathrm{C} 3 \% \mathrm{~A} 1$ torsk $\% \mathrm{C} 3 \% \mathrm{BD}$ p 1\%C 3\%A 1 n-environment \% C 3\%A 11 nav\%C3\%BDchova-2020-21.pdf

8. Štátny vzdelávací program pre 2. stupeň základnej školy v Slovenskej republike ISCED 2 - nižšie sekundárne vzdelávanie. URL: https://www.statpedu.sk/files/articles/ dokumenty/statny-vzdelavaci-program/ isced2 spu uprava.pdf

\section{REFERENCES}

1. Bilavych, H. (2020). Envaironmentalna osvita dlia staloho rozvytku u vymiri YuNESKO kriz pryzmu pidruchnykotvorennia [Environmental education for sustainable development from the unesco perspective through the prism of textbook creation]. "Youth and market". Monthly scientific-pedagogical journal. Drohobych, Vol. 3-4 (182-183), pp. 30-34. [in Ukrainian].

2. Tovkanets, H.V. \& Turok, O.S. (2020). Zmist osvity i vykhovannia uchniv serednoi shkoly v diialnosti slovatskykh ekolohichnykh orhanizatsii [The content of education and upbringing of secondary school students in the activities of Slovak environmental organizations]. Current issues of humanities: interuniversity collection of scientific works of young scientists. Drogobych, Vol. 4 (30), pp. 220-222. [in Ukrainian].

3. Turok, O.S. (2019). Ekolohichne prosvitnytstvo v umovakh neformalnoi osvity u Slovatskii respublitsi [Environmental education in the context of non-formal education in the Slovak Republic]. Scientific journal of Mukachevo State University. Series: Pedagogy and psychology. Mukachevo, Vol. 2(10)2,pp.93-96. [in Ukrainian].

4. Turok, O.S. Rol ekolohichnoho koordynatora $\mathrm{v}$ shkolakh Slovachchyny [The role of the environmental coordinator in schools in Slovakia]. Scientific Collection "InterConf", (31): with the Proceedings of the 7th International Scientific and Practical Conference "Science and Practice: Implementation to Modern Society". Manchester, Great Britain (October 6-8, 2020), pp.69-71. [in Ukrainian]. 


\section{ХАРАКТЕРИСТИКА МОДЕЛІ ФОРМУВАННЯ КОМУНІКАТИВНОЇ КОМПЕТЕНТНОСТІ ЗДОБУВАЧІВ ПОЧАТКОВОЇ ОСВІТИ}

5. Bernátová, R. (2013). Environmentálna výchova prierezová téma $\mathrm{v}$ základnej škole [Environmental education - a cross-sectional topic in primary school]. Current issues of science and technology subjects and cross-sectional topics in primary education. Online conference. 2325.10.2013, pp.13-25. [in Slovak].

6. Inovovaný školský vzdelávací program pre 1.a 2. Stupeň základnej školy s materskou školou Hôrky [Innovative school development program for 1.a 2. Level of basic school with kindergarten Hôrky]. URL: https:// zshorky.sk/wp-content/uploads/2019/10/ Inovovan $\% \mathrm{C} 3 \% \mathrm{BD}-\% \mathrm{C} 5 \% \mathrm{~A} 1 \mathrm{kolsk} \% \mathrm{C} 3 \% \mathrm{BD}$ vzde1\%C3\%A1vac\%C3\%AD-program-2020.pdf [in Slovak].
7. Plán práce školy v oblasti: environmentálna výchova. Šk. rok: $2020 / 2021$ [School work plan in the area: environmental education. School year: 2020/2021]. Available at: https://zshorky.sk/wp-content/uploads/2020/ $10 /$ Koordin $\% \mathrm{C} 3 \% \mathrm{~A} 1$ torsk $\% \mathrm{C} 3 \% \mathrm{BD}-\mathrm{pl} \% \mathrm{C} 3 \% \mathrm{~A} 1 \mathrm{n}$ environment $\% \mathrm{C} 3 \% \mathrm{~A} 1 \operatorname{lna}-\mathrm{v} \% \mathrm{C} 3 \%$ BDchova-2020-21.pdf [in Slovak].

8. Štátny vzdelávací program pre 2. stupeň základnej školy v Slovenskej republike ISCED 2 - nižšie sekundárne vzdelávanie [State educational program for the 2nd level of primary school in the Slovak Republic ISCED 2 - lower secondary education]. Available at: https:// www.statpedu.sk/files/articles/dokumenty/statnyvzdelavaci-program/isced2_spu_uprava.pdf_[in Slovak].

Стаття надійшла до редакції 26.11.2020

УДК 373.3.016:81-028.3

DOI:

Галина Подановська, викладач Педагогічного фахового коледжу Львівського начіонального університету імені Івана Франка

\section{ХАРАКТЕРИСТИКА МОДЕЛІ ФОРМУВАННЯ КОМУНІКАТИВНОЇ КОМПЕТЕНТНОСТІ ЗДОБУВАЧІВ ПОЧАТКОВОЇ ОСВІТИ}

Стаття присвячена проблемі аналізу експериментальної моделі формування комунікативноі компетентності здобувачів початкової освіти. Виокремлено основні компоненти моделі, підкреслюється їх важливість у прочесі формування комунікативної компетентності учнів початкової школи. Автор наголошує на взаємозв'язку компонентів моделі, які лише в комплексі дозволять домогтися більш високих навчальновиховних результатів в порівнянні з традиційною методикою підготовки кваліфікованого читача.

Ключові слова: модель; комунікативна компетентність; здобувачі початкової освіти; вчитель початкових класів; кваліфікований читач; літературне читання; уроки роботи з дитячою книжкою.

Puc. 1. Лim. 7.

Halyna Podanovska, Lecturer of Pedagogical Professional College of Lviv Ivan Franko National University

\section{CHARACTERISTIC OF THE MODEL OF THE FORMATION OF COMMUNICATIVE COMPETENCE OF PRIMARY SCHOOL PUPILS}

The article deals with the problem of the analysis of experimental model of the formation of the communicative competence of primary school pupils.

It is stated that nowadays great attention is paid to the acquiring of key competences by a person that are to provide his/her direction in a modern world, working out common strategy of constructive interaction with other people on the basis of mutual acceptance and mutual understanding as well as programming of the process of communication with them avoiding stable behaviour stereotypes. In this context the necessity to acquire one of key competences, communicative, is put on the first place, as with the help of the personality's ability and readiness to set and supply constructive interpersonal contacts and get the answer to necessary information is provided.

Though, the survey of the primary school teachers' experience shows that in a real educational process at the lessons of literary reading and work with children's book, the formation of communicative competence is often fragmentary without a whole system and necessary complexity of content and character of children's educational activity. Taking into consideration all the points, the need in the development of the model of the formation of communicative competence of primary school pupils arose.

The main components of the model were defined; their short characteristic is provided as well as their importance in the formation of communicative competence of primary school pupils. The author emphasizes the interconnection of the model components that only in complex can lead to higher educational result in comparison with the traditional methods of training of qualified reader.

Keywords: a model; communicative competence; primary school pupils; primary school teacher; qualified reader; literary reading; lessons with children's book. 